\title{
Effectiveness of real-time polymerase chain reaction assay for the detection of Mycobacterium tuberculosis in pathological samples: a systematic review and meta- analysis
}

Emmanuel O. Babafemi ${ }^{1 *}$, Benny P. Cherian², Lee Banting ${ }^{3}$, Graham A. Mills ${ }^{3}$ and Kandala Ngianga $\|^{4}$

\begin{abstract}
Background: Rapid and accurate diagnosis of tuberculosis (TB) is key to manage the disease and to control and prevent its transmission. Many established diagnostic methods suffer from low sensitivity or delay of timely results and are inadequate for rapid detection of Mycobacterium tuberculosis (MTB) in pulmonary and extra-pulmonary clinical samples. This study examined whether a real-time polymerase chain reaction (RT-PCR) assay, with a turn-around time of $2 \mathrm{~h}$, would prove effective for routine detection of MTB by clinical microbiology laboratories.
\end{abstract}

Methods: A systematic literature search was performed for publications in any language on the detection of MTB in pathological samples by RT-PCR assay. The following sources were used MEDLINE via PubMed, EMBASE, BIOSIS Citation Index, Web of Science, SCOPUS, ISI Web of Knowledge and Cochrane Infectious Diseases Group Specialised Register, grey literature, World Health Organization and Centres for Disease Control and Prevention websites. Fortysix studies met set inclusion criteria. Generated pooled summary estimates $(95 \% \mathrm{Cls}$ ) were calculated for overall accuracy and bivariate meta-regression model was used for meta-analysis.

Results: Summary estimates for pulmonary TB (31 studies) were as follows: sensitivity 0.82 ( $95 \% \mathrm{Cl} 0.81-0.83$ ), specificity 0.99 (95\% Cl 0.99-0.99), positive likelihood ratio 43.00 (28.23-64.81), negative likelihood ratio 0.16 (0.12-0. 20), diagnostic odds ratio 324.26 (95\% Cl 189.08-556.09) and area under curve 0.99. Summary estimates for extrapulmonary TB ( 25 studies) were as follows: sensitivity 0.70 ( $95 \%$ Cl 0.67-0.72), specificity 0.99 ( $95 \%$ Cl 0.99-0.99), positive likelihood ratio 29.82 (17.86-49.78), negative likelihood ratio 0.33 (0.26-0.42), diagnostic odds ratio 125.20 (95\% Cl 65.75-238.36) and area under curve 0.96 .

Conclusions: RT-PCR assay demonstrated a high degree of sensitivity for pulmonary TB and good sensitivity for extra-pulmonary TB. It indicated a high degree of specificity for ruling in TB infection from sampling regimes. This was acceptable, but may better as a rule out add-on diagnostic test. RT-PCR assays demonstrate both a high degree of sensitivity in pulmonary samples and rapidity of detection of TB which is an important factor in achieving effective global control and for patient management in terms of initiating early and appropriate anti-tubercular therapy.

\section{Systematic review registration: PROSPERO CRD42015027534.}

Keywords: Tuberculosis, Mycobacterium tuberculosis, Real-time polymerase chain reaction assay, Pulmonary samples, Extra-pulmonary samples, Systematic review, Meta-analysis

\footnotetext{
*Correspondence: boladiipo95@yahoo.com

'Microbiology Department, Pathology Division, Sandwell and West

Birmingham Hospitals NHS Trust, Birmingham, UK

Full list of author information is available at the end of the article
} 


\section{Background}

Tuberculosis (TB), an infectious disease caused by the bacillus Mycobacterium tuberculosis (MTB), is spread from person to person predominantly through an airborne route. It remains a major global health problem as it causes ill-health among millions of people. After the human immunodeficiency virus (HIV), TB ranks as the second leading cause of death from an infectious disease worldwide $[1,2]$. The lack of a simple and effective diagnostic test that can be utilised in resource-limited settings, where the infection is endemic, has hindered its control [3]. According to the World Health Organization in 2015, there were 10.4 million new cases of TB worldwide that resulted in 1.8 million deaths and over 95\% were from low- and middle-income countries [4, 5]. In the UK, a total of 5758 TB cases were notified the by Public Health England in 2015 [6].

Over the past decade, the TB diagnostics pipeline has expanded, with several technologies showing promise [7]. New diagnostic tests are continually being developed, driven by demands for improvements in speed, cost, ease of use, patient safety and diagnostic accuracy [8]. Consequently, there are often several tests available for the diagnosis of a condition. Polymerase chain reaction (PCR) technology was introduced in the mid-1990s and has revolutionised the diagnosis of infectious diseases. Nucleic acid amplification assays (NAAAs) are commonly used in routine laboratories in industrialised countries for rapid and specific detection of MTB complex in clinical specimens. Over time, a significant improvement of PCR technologies has been achieved with the development of real-time polymerase chain reaction (RT-PCR) assay testing platforms. RT-PCR assay is commonly used to determine whether DNA or a sequence of the MTB is present in a sample and detects amplified DNA as the reaction progresses in real time. It monitors the amplification of a targeted DNA/RNA molecule during the PCR amplification by using complementary primers, i.e. in real-time, and not at its end, as in conventional PCR. A RT-PCR assay uses marked probes with fluorophores that emit fluorescence alongside amplification. The cycle of the PCR protocol in which there appears significant fluorescence is proportional to the quantity of DNA/RNA present in the sample. This value is called cycle threshold $\left(C_{\mathrm{t}}\right)$ or cycle quantification $\left(C_{\mathrm{q}}\right)$. RT-PCR is sensitive, specific and reproducible, and automation of the procedure reduces hands-on time and decreases the risk of cross-contamination [9].

RT-PCR-based methods have been shown to detect MTB with higher sensitivity and specificity directly from positive cultures or clinical specimens within $2 \mathrm{~h}$ [10]. It requires approximately 6 copies/ml of MTB DNA in comparison to smear microscopy that requires 500010,000 bacilli/ml. For concentrated samples, such as sputum, sensitivity of smear microscopy has been reported to increase up to $39 \%$. Culture which is the reference standard, requires at least 100 viable bacilli to obtain a positive culture with a turn-a-round time of between 2 and 10 weeks [11]. Therefore, to adequately treat and effectively control MTB, there is a need for effective, rapid and accurate diagnosis.

This review assesses all the available published primary research studies to provide summary estimates of the effectiveness of RT-PCR assay for the detection of MTB from pulmonary and extra-pulmonary samples. It summarises current evidence-based clinical practice that can help to develop future guidelines and healthcare policy when choosing the most appropriate tool for rapid and accurate detection of MTB in pathological samples on routine basis.

\section{Methods}

This review is in accord with the standardised written protocol (systematic review registration: PROSPERO CRD42015027534) that followed the PRISMA (Preferred Reporting Items for Systematic Reviews and MetaAnalyses) statement guidelines [12]. Additional file 1 shows the PRISMA checklist. Quality of included studies was assessed by Quality Assessment of Diagnostic Accuracy Studies-2 (QUADAS-2) [13]. Institutional ethical review approval was not needed for this review.

\section{Strategy \\ Electronic searches}

Search terms (included 'tuberculosis', 'Mycobacterium tuberculosis,' 'pulmonary tuberculosis', 'extra-pulmonary tuberculosis,' 'real-time polymerase chain reaction,' RT-PCR,' 'nucleic acid amplification test', 'culture-based media, 'liquid media' and 'solid media') (see Additional file 2 for search terms) were used to generate a list of primary studies in any language from January 1995 to November 2016 (RT-PCR became a tool for detecting and quantifying expression profiles of selected genes in the mid-1990s. A search using the key words real-time and PCR yielded seven publications in 1995). Two investigators (EB, BC) independently and systematically carried out the search. Searches using electronic bibliographic databases (MEDLINE via PubMed, EMBASE, BIOSIS Citation Index, Web of Science, SCOPUS, ISI Web of Knowledge, Cochrane Infectious Diseases Group Specialised Register (CIDG SR), Cochrane Registry of Diagnostic Studies, National Institute for Health Research, PROSPERO, Google Scholar Turning Research into Practice (TRIP) and International Union Against Tuberculosis and Lung Disease (IUALTD)) took place in July 2015 and was updated in November 2016. The MEDLINE search strategy is outlined in Additional file 2. The MEDLINE search was imported to EMBASE, Cochrane Infectious Diseases Group Specialised Register and other databases to 
identify additional records $[14,15]$. These attempts to avoid missing studies achieve a more reliable estimate of diagnostic accuracy which is important to ensure that the process of identifying studies is as thorough and unbiased as possible.

We reviewed reference lists of included articles and any relevant review articles identified through the above methods. Conference Proceedings Citation Index-Science (CPCI-S) was searched. We searched the portal of the World Health Organization (WHO) International Clinical Trials Registry Platform (http://www.who.int/trialsearch), to identify ongoing trials and StopTB Partnership's New Diagnostics Working Group (www.stoptb.org/ wg/new_diagnostics/). Personal communication was sent to the corresponding author of 'Detection of Mycobacterial DNA directly from FNAC samples of tuberculous lymphadenopathy using real-time PCR: a preliminary study' to ask for study data. Forward citation searching of relevant articles using the PubMed related articles and relevant guidelines (i.e. National Institute for Health and Care Excellence (NICE) in the UK) was performed. Focus was placed on TB meetings for example annual scientific conferences of $\mathrm{TB}$ diagnosis and control such as the IUALTD. Besides full articles, abstracts and letters to the editor with sample sizes $>20$ were also considered for inclusion. There was no language limitation to the search. Abstracts or articles in languages other than English were screened using 'Google Translator'.

\section{Inclusion and exclusion criteria}

Study designs such as cross-sectional studies, cohort studies (prospective and retrospective) and case-control designs for the detection of MTB from human pathological samples of any patient age were eligible for inclusion if the studies (1) described original research, (2) compared RT-PCR assay to a reference/gold standard method- culture-based (either liquid or solid) assay, (3) reported total number of patients tested and positive/ negative results that allowed calculation of true positives (TP), true negatives (TN), false positives (FP) and false negatives (FN) and (4) were published between 1995 and 2016 in any language. Studies were excluded if (1) all samples were not tested by reference/gold standard test-culture-based (either liquid or solid) assay, (2) application of RT-PCR assay for determining drug resistance, (3) RT-PCR assay was not used in the study, (4) reference test was a combination of greater than one diagnostic test, (5) it included animal studies, (6) RTPCR assay was used for detecting non-tuberculosis mycobacteria, (7) RT-PCR assay was used for detecting MTB from clinical isolates and not the pathological specimens/samples and (8) possible duplicate publication, when an author published more than one study. The existence of overlapping study populations was ascertained by checking sample recruitment sites and/or periods. The article reporting on the largest number of samples was included in our study.

\section{Selection of studies}

Full-text articles were screened independently (by EB and $\mathrm{BC}$, using a PRISMA flow chart [12]) for eligibility for use in the study to minimise bias in selection. Any disagreements were resolved through discussion and where needed, by a third reviewer. Any rejected studies were documented.

\section{Data extraction}

Data were extracted (independently by EB and BC) from each selected study using a predetermined list of categories/characteristics: participants/population, index test, reference test, country, disease and target sequence for detection of MTB DNA (Table 1).

\section{Assessment of study quality}

The methodological quality for the included studies was assessed independently (EB and $\mathrm{BC}$ ) according to the four domains (patient selection, index test, reference standard and flow and timing) of the QUADAS-2 tool [13]. The study QUADAS-2 quality criteria are given in Additional file 3.

\section{Data synthesis and meta-analysis}

For each study, we computed measures of test accuracy using standard methods recommended for meta-analysis of diagnostic studies: sensitivity, specificity, positive likelihood ratio (PLR), negative likelihood ratio (NLR), diagnostic odds ratio (DOR) and 95\% confidence intervals (CI) [16-18] see Additional file 4. TP, FP, TN and FN were extracted directly from source papers. Where this information was not available, values were calculated from the data provided in the article. To assess the overall accuracy, a DOR was calculated using the DerSimonian-Laird random-effect model, which accounts for both within-study variability (random error) and between-study variability (heterogeneity) along with the area under the summary receiver operating characteristic (SROC) curve using the bivariate model $[17,18]$. The bivariate model considers potential threshold effects and the correlation between binary tests (sensitivity and specificity). These measures were pooled using the random-effects model $[17,18]$. Each study in the metaanalysis contributed a pair of numbers: sensitivity and specificity. Since these measures are correlated, we summarised their joint distribution using a SROC curve. The SROC curve presents a global summary of test performance and shows the trade-off between sensitivity and specificity. A symmetric curve suggests that the variability in accuracy between studies is explained, in part, by 
Table 1 Characteristics of the included studies

\begin{tabular}{|c|c|c|c|c|c|c|}
\hline \multirow[t]{2}{*}{ Author year [n] } & \multirow[t]{2}{*}{ Country } & \multicolumn{2}{|c|}{$\begin{array}{l}\text { Total number of } \\
\text { samples }(N)\end{array}$} & \multirow[t]{2}{*}{ Reference test: culture } & \multirow[t]{2}{*}{ Index test RT-PCR } & \multirow[t]{2}{*}{ Target sequence } \\
\hline & & PTB & EPTB & & & \\
\hline Albuquerque, 2014 [24] & Brazil & 140 & - & LJ 7H9 & TaqMan & IS6110 gene \\
\hline Antonenka, 2013 [25] & Germany & 116 & - & MGIT LJ & TaqMan & rpoB as target sequence \\
\hline Armand, 2011 [26] & France & 70 & 47 & L BacT/Alert MP & TaqMan & IS6110 gene \\
\hline Barletta, 2014 [27] & Belgium & 112 & - & $\sqcup J$ & $\begin{array}{l}\text { Light Cycler } 480 \\
\text { Real-time PCR assay }\end{array}$ & IS6110 gene \\
\hline Bloemberg, 2013 [28] & Switzerland & 829 & 280 & 7H11 MGIT & COBAS TaqMan & $16 \mathrm{~S}$ rRNA gene \\
\hline Causse, 2011 [23] & Spain & - & 340 & $\sqcup 7 \mathrm{H} 9$ & COBAS TaqMan MTB & $16 \mathrm{~S}$ rRNA gene \\
\hline Chadran, 2010 [29] & India & 72 & - & LJ MGIT 960 & COBAS TaqMan & IS6110 gene \\
\hline Chaidir, 2012 [30] & Indonesia & - & 207 & $\begin{array}{l}\text { Ogawa egg } \\
\text { medium MB/BacTalert }\end{array}$ & IS6110-PCR BioRad & IS6110 gene \\
\hline Chang, 2015 [31] & South Korea & 2859 & - & MGIT 960 3\% Ogawa & $\begin{array}{l}\text { AdvanSure TB/NTM } \\
\text { Real-time PCR assay }\end{array}$ & IS6110 gene \\
\hline Chen, 2012 [32] & China & 178 & - & 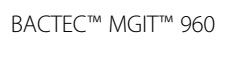 & $\begin{array}{l}\text { Real-time PCR assay used } \\
\text { the ABI Prism SDS } 7000\end{array}$ & IS6110 gene \\
\hline Chitnis, 2010 [33] & India & - & 204 & LJ MGIT-BACTEC & $\begin{array}{l}\text { Geno-Sen's MTB complex } \\
\text { Real-time PCR assay }\end{array}$ & 165 rRNA gene \\
\hline Cho, 2015 [34] & South Korea & 2384 & 626 & $\begin{array}{l}\text { 2\% Ogawa medium } \\
\text { MGIT } 960\end{array}$ & COBAS TaqMan MTB assay & IS6110 gene \\
\hline Choe, 2011 [35] & South Korea & - & 129 & $3 \%$ Ogawa & TaqMan & $\begin{array}{l}\text { Real-time MTB PCR, } \\
\text { targeting the senX3-regX3 } \\
\text { intergenic region }\end{array}$ \\
\hline Choi, 2013 [36] & South Korea & 360 & 65 & MGIT 960 & COBAS TaqMan MTB assay & IS6110 gene \\
\hline Dayal, 2010 [37] & India & - & 47 & BacT/Alert & $\begin{array}{l}\text { Real-time PCR targeting } \\
16 S \text { SRNA } \\
\text { using Light Cycler RNA } \\
\text { amplification syber green } \\
1 \text { kit (Roche Applied } \\
\text { Biosciences, Germany) }\end{array}$ & $16 \mathrm{~S}$ rRNA gene \\
\hline El Khechine, 2009 [38] & France & - & 134 & BACTEC $9000 \mathrm{MB} \sqcup \mathrm{J}$ & Not specified & IS6110 gene \\
\hline Feizabadi, 2012 [39] & Iran & 247 & - & $\llcorner J$ & TaqMan & $\begin{array}{l}\text { Cytochrome P450 Cyp } \\
141 \text { gene }\end{array}$ \\
\hline Friedrich, 2011 [40] & South Africa & - & 25 & MGIT 960 & Xpert & rpoB probe \\
\hline Gous, 2012 [41] & South Africa & - & 39 & BACTEC $9000 \mathrm{MB} \sqcup$ & $\begin{array}{l}\text { Light Cycler mycobacterium } \\
\text { detection assay (LCTB) }\end{array}$ & \\
\hline Hillemann, 2011 [42] & Germany & - & 521 & MGIT $960 \sqcup$ & $\begin{array}{l}\text { GenoType MTBC and } \\
\text { CM/AS assays (Hain Lifescience) }\end{array}$ & rpoB probe \\
\hline Hofmann-Thiel, 2016 [43] & Germany & 608 & 107 & MGIT LJ & Abbott Real-time MTB & $\begin{array}{l}\text { Antigen } b(P A B) \text { and the } \\
\text { multicopy insertion } \\
\text { element IS6110 gene }\end{array}$ \\
\hline Huh, 2015 [44] & South Korea & 6852 & - & MGIT $960 \sqcup$ & COBAS TaqMan & $16 \mathrm{~S}$ rRNA gene \\
\hline In, 2014 [45] & South Korea & 247 & - & BACTEC MGIT $960 \mathrm{~L}$ & $\begin{array}{l}\text { Ultrafast NBS LabChip G2-3 } \\
\text { (NanoBioSys) }\end{array}$ & \\
\hline Jönsson, 2015 [46] & Sweden & 2388 & 1005 & MGIT $960 \sqcup$ & COBAS TaqMan & $16 \mathrm{~S}$ rRNA gene \\
\hline Kheawon, 2012 [47] & Thailand & 430 & - & $\llcorner J$ medium & Commercial PCR Kits Amplicor & $\begin{array}{l}\text { IS6110 gene and } \\
\text { MPB64 gene }\end{array}$ \\
\hline Kim, $2011[48]$ & South Korea & 96 & 310 & Solid culture & $\begin{array}{l}\text { Ultrafast NBS LabChip G2-3 } \\
\text { system (NanoBioSys) }\end{array}$ & $\begin{array}{l}61 \text { genomic DNA (gDNA) } \\
\text { samples of MTB }\end{array}$ \\
\hline Lee, 2011 [49] & South Korea & 99 & - & $3 \%$ Ogawa & $\begin{array}{l}\text { AdvanSure TB/NTM Real-time } \\
\text { PCR assay }\end{array}$ & IS6110 gene \\
\hline Lee, 2010 [50] & South Korea & - & 143 & $3 \%$ Ogawa & Light Cycler 2.0 & $\begin{array}{l}\text { senX3-regX3 intergenic } \\
\text { region }\end{array}$ \\
\hline Lee, 2013 [51] & Taiwan & 587 & - & BACTEC MGIT 960 LJ & COBAS TaqMan MTB assay & IS6110 gene \\
\hline Lim, 2014 [52] & South Korea & 1167 & & & COBAS TaqMan MTB assay & \\
\hline Linasmita, 2012 [53] & Thailand & - & 73 & MGIT 960 & COBAS TaqMan MTB assay & $\begin{array}{l}165 \text { ribosomal RNA } \\
\text { gene of } M \text {. tuberculosis }\end{array}$ \\
\hline
\end{tabular}


Table 1 Characteristics of the included studies (Continued)

\begin{tabular}{|c|c|c|c|c|c|c|}
\hline \multirow[t]{2}{*}{ Author year [n] } & \multirow[t]{2}{*}{ Country } & \multicolumn{2}{|c|}{$\begin{array}{l}\text { Total number of } \\
\text { samples }(N)\end{array}$} & \multirow[t]{2}{*}{ Reference test: culture } & \multirow[t]{2}{*}{ Index test RT-PCR } & \multirow[t]{2}{*}{ Target sequence } \\
\hline & & $\overline{\mathrm{PTB}}$ & EPTB & & & \\
\hline Lira, 2013 [54] & Brazil & 165 & - & $\sqcup J$ & $\begin{array}{l}\text { ABI Prism } 7500 \text { Sequence } \\
\text { Detection System (Applied } \\
\text { Biosystems) using } \\
\text { TaqMan-specific probe }\end{array}$ & IS6110 gene \\
\hline Luo, 2010 [55] & USA & - & 70 & $\begin{array}{l}\text { Culture-based assay } \\
\text { (type not stated) }\end{array}$ & SmartCycler II instrument & IS6110 gene \\
\hline Malhotra, 2012 [56] & India & - & 555 & 7H9 & COBAS Taqman & IS6110 gene \\
\hline Mangat, 2016 [57] & India & 74 & - & MGIT $960 \sqcup$ & $\begin{array}{l}\text { Roche Light Cycler } 480 \\
\text { Real-time PCR system }\end{array}$ & $\begin{array}{l}123 \mathrm{bp} \text { fragment of } \\
\text { insertion element IS6110 } \\
\text { sequence }\end{array}$ \\
\hline Miller, 2011 [58] & North Carolina, USA & 89 & 23 & 7H9 ᄂ & Xpert & $\begin{array}{l}\text { Laboratory-developed } \\
\text { test targeting IS6110 gene }\end{array}$ \\
\hline Moure, 2012 [59] & Spain & - & 149 & MGIT $960 \sqcup$ & GX assay & \\
\hline Park, 2013 [60] & South Korea & 320 & - & MGIT 960 3\% Ogawa & COBAS TaqMan & IS6110 gene \\
\hline Pinhata, 2015 [61] & Brazil & 715 & - & MGIT 960 Ogawa-Kudoh slant & Roche Light Cycler 480 || system & mpt64 gene \\
\hline Rachow, 2011 [11] & Tanzania & 292 & - & Both liquid and solid (type not stated) & Cepheid Xpert MTB/RIF assay & rpoB as target gene \\
\hline Rosso, $2011[62]$ & Brazil & - & 158 & LJ & $\begin{array}{l}\text { ABI Prism } 7500 \text { system } \\
\text { (Applied Biosystems) }\end{array}$ & IS6110 gene \\
\hline Sethi, 2012 [63] & India & 50 & 22 & MGIT $960 \sqcup$ & In-house mpt64 Real-time PCR & mpt64 gene \\
\hline Sharma, 2015 [64] & India & 1480 & - & MGIT $960 \sqcup$ & $\begin{array}{l}\text { ABI prism 3130xl genetic } \\
\text { analyser (Applied Biosystems) }\end{array}$ & 81-bp rpoB gene \\
\hline Tortoli, 2012 [65] & Italy & 4340 & 1727 & MGIT $960 \sqcup$ & Cepheid Xpert MTB/RIF assay & rpoB as target gene \\
\hline Wang, 2013 [66] & China & 30 & - & Bact/Alert 3D & Light Cycler 480 (Roche) & \\
\hline Yang, 2011 [67] & Taiwan & 1093 & - & MGIT 960 ᄂ 7H11 & COBAS TaqMan MTB assay & IS6110 gene \\
\hline
\end{tabular}

Key: $L$ Löwenstein-Jensen, Middlebrook 7 H9 Broth Liquid growth medium, Middlebrook 7 H11 Solid medium, MGIT Mycobacterium Growth Indicator Tube, PTB Pulmonary TB, EPTB Extra-pulmonary TB, [n] reference list number

differences in thresholds used by the studies. The area under the SROC curve is a global measure of overall performance of the test. An area under the curve value of 1 indicates perfect discriminatory ability of the test, while an area under the curve value of 0.5 means that the test does not have discriminating ability $[17,18]$.

Data were analysed using Meta-DiSC (version 1.4), Reviewing Manager ver. 5.3 (Cochrane Collaboration, Oxford, UK) [18, 19]. The data were displayed graphically on forest plots and SROC plots. The SROC curve was fitted using the Littenberg-Moses method [20].

Publication bias was not evaluated as this is not usually recommended in the meta-analysis for diagnostic test accuracy [21]. Generally, a diagnostic accuracy study does not test a hypothesis; therefore, there is no $p$ value for authors and publishers that may influence decisions about publication which are based on the statistical significance of the results [22].

\section{Investigations of heterogeneity}

Exploring heterogeneity is a critical issue (1) to understand the possible factors that influence accuracy estimates and (2) to evaluate the appropriateness of statistical pooling of accuracy estimates using random- effects meta-analysis to generate sensitivity and specificity with $95 \%$ CIs from various studies [22].

The heterogeneities among studies were assessed visually with forest plots and SROC curves with 95\% prediction regions and statistically with chi-squared $\left(\chi^{2}\right)$ and using I-squared $\left(I^{2}\right)$ statistics with the following interpretation: $I^{2}=0$, no heterogeneity; $0<I^{2}<25$, mild heterogeneity; $25 \leq I^{2}<50$, moderate heterogeneity; $50 \leq I^{2}<75$, strong heterogeneity; $75 \leq I^{2}<90$, considerable heterogeneity and $90 \leq I^{2}$, extreme heterogeneity [23]. Source of heterogeneity was investigated using stratified (subgroup) analyses. The following factors were specified a priori as potential sources of heterogeneity (1) studies of RT-PCR assay type: CobasTaqMan as the RT-PCR assay, Light Cycler as the RT-PCR assay, Cepheid \& others and (2) RT-PCR assay target sequence gene: IS6110 as the RT-PCR assay target sequence gene, 16SRNA as the RT-PCR assay target sequence gene and other genes as the RT-PCR assay (see Tables 1, 3 and 4).

\section{Results}

Study characteristics

Of the 6706 references that were identified initially, 1628 potentially relevant citations were selected based on relevance to the study topic. An additional 27 studies 
were identified from grey literature and references of full-text articles. After screening all the titles and abstracts, removing the duplicates and excluding the ineligible studies, 46 articles [10, 23-67] were selected for full-text review and meta-analysis (Fig. 1). Twenty-one $[10,24,25,27,29,31,32,39,44,45,47,49,51,52,54$, $57,60,61,64,66,67]$ reported detection of pulmonary TB (РTB), fifteen $[23,30,33,35,37,38,40-42,50,53$, $55,56,59,62]$ reported detection of extra-pulmonary TB (ЕРTB) and ten [26, 28, 34, 36, 43, 46, 48, 58, 63, 65] reported on both types of pathological sample. Table 1 summarises the main characteristics of the included studies. In total, the review and meta-analysis included 35,380 (28,406 PTB and 6974 EPTB) pathological samples obtained from 21 countries with high, moderate and low prevalence of TB. Studies included patients with infections identified in primary, secondary and tertiary healthcare settings. Details of the RT-PCR assays used are summarised in Table 1.

The methodological quality of studies (assessed by the QUADAS-2 tool) was generally high, with 37 of the studies meeting all four domains of the criteria (see Figs. 2 and 3). All studies used RT-PCR assay as index test and culture-based assay as the reference test.

\section{Meta-analysis}

Results as 95\% CI values were as follows: overall sensitivity 0.82 (95\% CI $0.81-0.83$ ) and 0.70 (95\% CI $0.67-$ 0.72 ) and the values and confidence intervals for specificity are similar 0.99 (95\% CI $0.99-0.99)$ for PTB and EPTB samples, respectively. AUC was 0.99 and 0.96 for PTB and EPTB samples, respectively. The summary estimates of PTB for heterogeneity with chi-squared $\left(x^{2}\right)$ using 95\% CI for sensitivity, specificity, PLR, NLR and DOR were 586.21, 361.23, 285.01, 359.13 and 242.84, respectively, and $p=0$ indicating significant heterogeneity across studies. $I^{2}$ was between 87.60 and $92.80 \%$ showing significant heterogeneity. The summary estimates of EPTB heterogeneity with chi-squared $\left(\chi^{2}\right)$ using 95\% CI for sensitivity, specificity, PLR, NLR and DOR were $272.48,105.48,75.37,186.30$ and 70.73 , respectively, and $p=0$ indicating significant heterogeneity across studies. $I^{2}$ was between 66.10 and $91.20 \%$ showing significant heterogeneity. There were considerable heterogeneities (see Table 2, Figs. 4 and 5) in these data.

\section{Subgroup analyses by RT-PCR assay type}

I. With CobasTaqMan (Table 1) as the RT-PCR assay (17 studies, 19,814 specimens), the results were as follows: sensitivity 0.78 (95\% CI $0.76-0.80$ ), specificity 10.99 (95\% CI, 0.99-0.99) and AUC 0.98. A test with perfect discrimination has a ROC curve that passes through the upper left corner $(100 \%$ sensitivity, 100\% specificity). The closer the ROC curve to the upper left corner, the higher the overall accuracy of the test. The summary estimates of CobasTaqMan heterogeneity with chi-squared $\left(x^{2}\right)$ using 95\% CI for sensitivity, specificity, PLR, NLR and DOR were 205.13, 127.21, 98.14, 134.36 and 47.6 , respectively, and $p=<0.001$ indicating significant heterogeneity across studies. $I^{2}$ was between 70.50 and $91.20 \%$ showing significant heterogeneity. The results for subgroup analysis by RT-PCR assay type are as presented in Table 3 and Additional file 5 and show considerable heterogeneity.

II. With Light Cycler (Table 1) as the RT-PCR assay (7 studies, 1159 specimens), the results were as follows: sensitivity 0.85 (95\% CI $0.80-0.88$ ), specificity 0.99 (95\% CI 0.98-0.99) and AUC 0.97. A test with perfect discrimination has a ROC curve that passes through the upper left corner (100\% sensitivity, $100 \%$ specificity). The closer the ROC curve to the upper left corner, the higher the overall accuracy of the test. The summary estimates of Light Cycler heterogeneity with chi-squared $\left(\chi^{2}\right)$ using 95\% CI for sensitivity, specificity, PLR, NLR and DOR were $61.71,10.09,17.45,63.77,20.35$ respectively and $p=<0.121$ indicating significant heterogeneity across studies. $I^{2}$ was between 66.40 and $90.30 \%$ showing significant heterogeneity. The results for subgroup analysis by RT-PCR assay type are as presented Table 3 and Additional file 5 and show considerable heterogeneity.

III.With Cepheid and others (Table 1) as the RT-PCR assay (22 studies, 14,839 specimens), the results were as follows: sensitivity 0.78 (95\% CI 0.77-0.80), specificity 0.99 (95\% CI 0.99-0.99) and AUC 0.99. A test with perfect discrimination has a ROC curve that passes through the upper left corner (100\% sensitivity, $100 \%$ specificity). The closer the ROC curve to the upper left corner, the higher the overall accuracy of the test. The summary estimates of Cepheid and others heterogeneity with chi-squared $\left(x^{2}\right)$ using $95 \%$ CI for sensitivity, specificity, PLR, NLR and DOR were $729.43,299.13,234.62,594.30$ and 208.25 , respectively, and $p=0$ indicating significant heterogeneity across studies. $I^{2}$ was between 89.90 and 97.10\% showing significant heterogeneity. The results for subgroup analysis by RT-PCR assay type are as presented Table 3 and Additional file 5 and show considerable heterogeneity.

\section{Subgroup analyses by RT-PCR assay target sequence gene}

I. With IS6110 as the RT-PCR assay target sequence gene (22 studies, 12,004 specimens), the results were 
PRISMA 2009 Flow Diagram
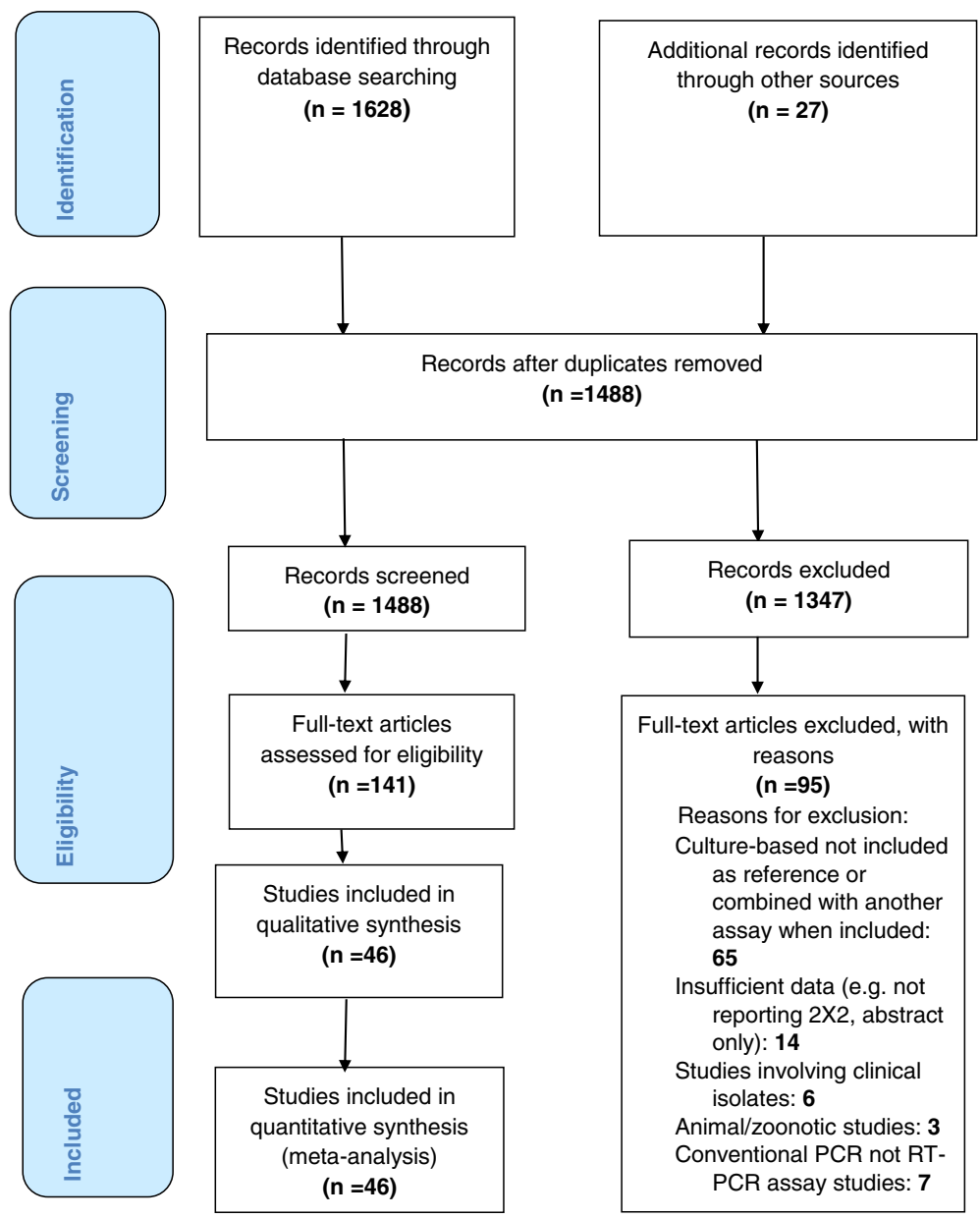

( $\mathrm{n}=\mathbf{1 4 8 8})$
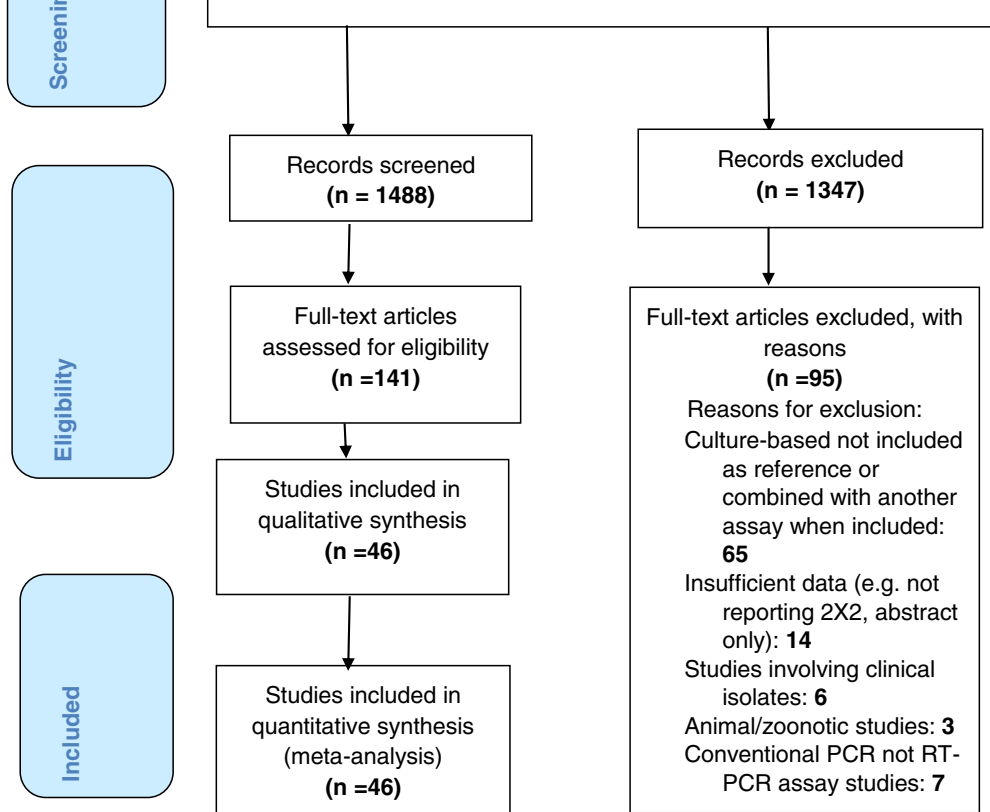

Fig. 1 The Preferred Reporting Items for Systematic Reviews and Meta-Analyses (PRISMA)

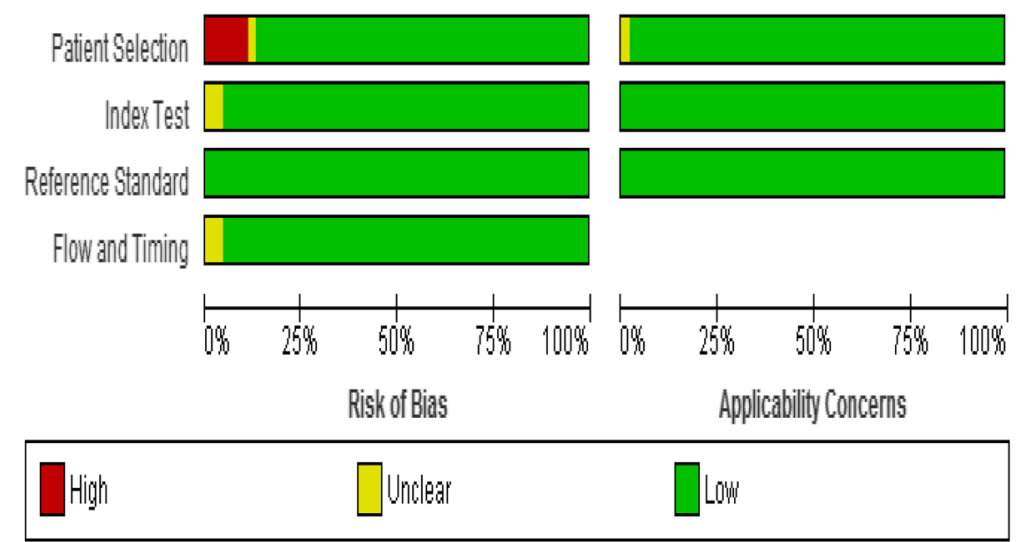

Fig. 2 Risk of bias and applicability concerns graph: review authors' judgements about each domain presented as percentages across included studies 


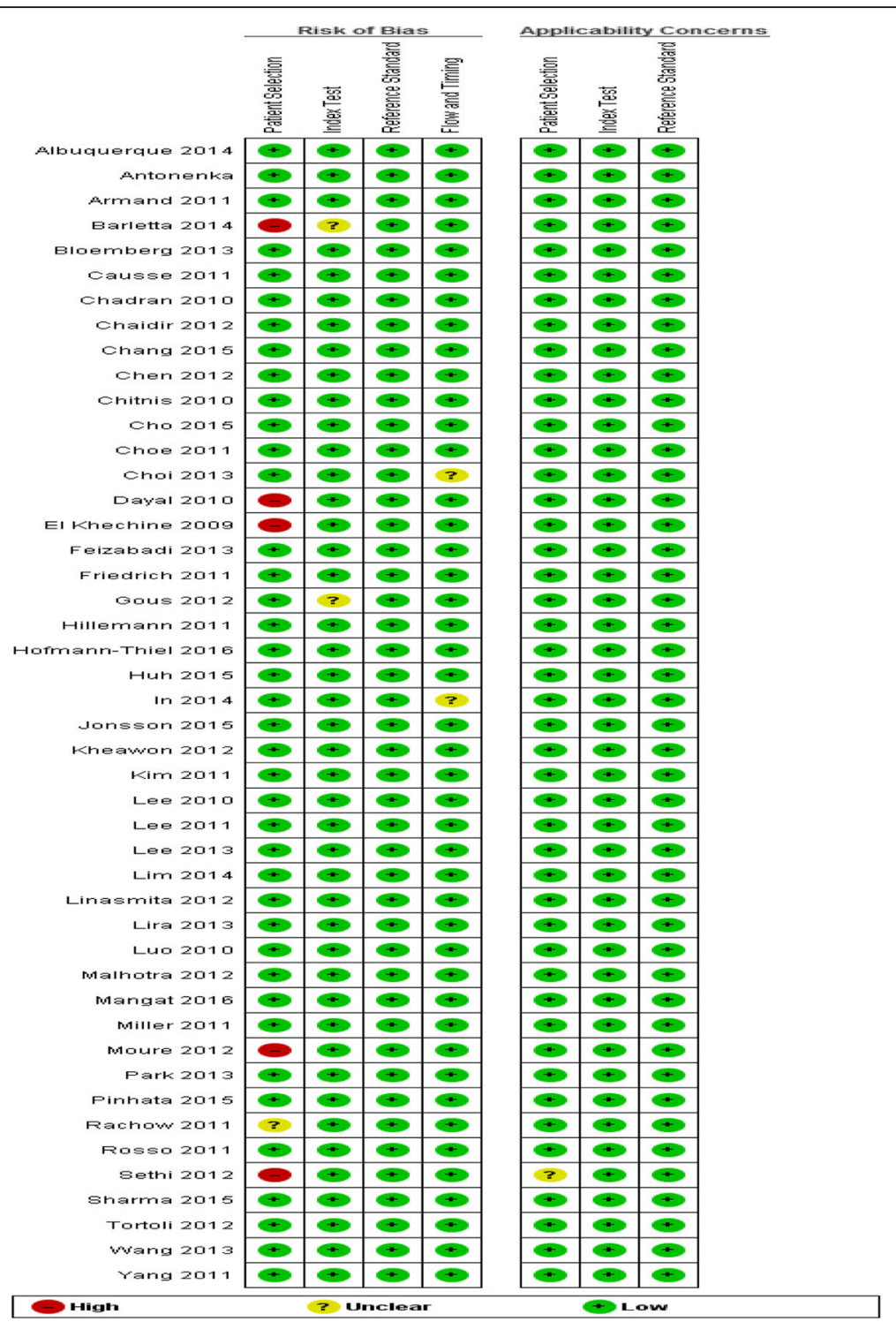

Fig. 3 Risk of bias and applicability concerns summary: review authors' judgements about each domain for each included study

as follows: sensitivity $0.79(0.77-0.81)$, specificity 0.98 (0.98-0.98) and AUC 0.99. A test with perfect discrimination has a ROC curve that passes through the upper left corner (100\% sensitivity, $100 \%$ specificity). The closer the ROC curve to the upper left corner, the higher the overall accuracy of the test. The summary estimates of IS6110 heterogeneity with chi-squared $\left(\chi^{2}\right)$ using 95\% CI for sensitivity, specificity, PLR, NLR and DOR were 470.30, 150.16, 134.64, 356.22 and 141.04, respectively, and $p=0$ indicating significant heterogeneity across studies. $I^{2}$ was between 85.10 and $95.50 \%$ showing significant heterogeneity. The results for subgroup analysis by RT-PCR assay target sequence gene are presented in
Table 4 and Additional file 5 and show considerable heterogeneity.

II. With $16 \mathrm{~S}$ rRNA as the RT-PCR assay target sequence gene (7 studies, 12,074 specimens), the results were as follows: sensitivity $0.69(0.66-0.71)$, specificity 0.99 (0.99-0.99) and AUC 0.97. A test with perfect discrimination has a ROC curve that passes through the upper left corner (100\% sensitivity, $100 \%$ specificity). The closer the ROC curve to the upper left corner, the higher the overall accuracy of the test $\left(x^{2}\right)$ using $95 \%$ CI for sensitivity, specificity, PLR, NLR and DOR were 45.85, 32.10, 34.60, 19.87 and 9.12, respectively, and $p<0.167$ indicating significant heterogeneity across studies. $I^{2}$ was between 86.90 and $34.20 \%$ showing significant 
Table 2 Summary of statistical results for pulmonary tuberculosis (PTB) and extra-pulmonary tuberculosis (EPTB) pathological samples

\begin{tabular}{|c|c|c|c|c|}
\hline \multirow[t]{2}{*}{ Test property } & \multirow{2}{*}{$\begin{array}{l}\text { Summary measure of } \\
\text { test accuracy }{ }^{\mathrm{a}} \text { ( } 95 \% \\
\text { Cl) }\end{array}$} & \multicolumn{3}{|c|}{ Test for heterogeneity } \\
\hline & & $\left(x^{2}\right)(d f=24)$ & $\left(1^{2}\right)$ & $\overline{p \text { value }}$ \\
\hline \multicolumn{5}{|l|}{$\overline{\mathrm{PTB}}\left(n=31 ;{ }^{\mathrm{b}} 28,406\right) \mathrm{AUC}=0.99$} \\
\hline Sensitivity & $0.82(0.81-0.83)$ & 586.21 & $92.8 \%$ & $<0.001$ \\
\hline Specificity & $0.99(0.99-0.99)$ & 361.23 & $91.7 \%$ & $<0.001$ \\
\hline Positive likelihood ratio (PLR) & $42.77(28.23-64.81)$ & 285.01 & $89.5 \%$ & $<0.001$ \\
\hline Negative likelihood ratio (NLR) & $0.16(0.12-0.20)$ & 359.13 & $91.6 \%$ & $<0.001$ \\
\hline Diagnostic odds ratio (DOR) & $324.26(189.08-556.09)$ & 242.84 & $87.6 \%$ & $<0.001$ \\
\hline \multicolumn{5}{|l|}{ EPTB $\left(n=25 ;{ }^{b} 6974\right)$ AUC $=0.96$} \\
\hline Sensitivity & $0.70(0.67-0.72)$ & 272.48 & $91.20 \%$ & $<0.001$ \\
\hline Specificity & $0.99(0.99-0.99)$ & 105.48 & $77.20 \%$ & $<0.001$ \\
\hline Positive likelihood ratio (PLR) & $29.82(17.86-49.78)$ & 75.37 & $68.20 \%$ & $<0.001$ \\
\hline Negative likelihood ratio (NLR) & $0.33(0.26-0.42)$ & 186.30 & $87.10 \%$ & $<0.001$ \\
\hline Diagnostic odds ratio (DOR) & $125.20(65.76-238.36)$ & 70.73 & $66.10 \%$ & $<0.001$ \\
\hline
\end{tabular}

$X^{2}$ chi-squared, $d f$ degree of freedom, $I^{2}$ I-squared, $n$ number of studies, $C l$ confidence interval, AUC area under receiver operating characteristics curve, PTB pulmonary tuberculosis, EPTB extra-pulmonary tuberculosis

${ }^{\mathrm{a}}$ Random-effects model

${ }^{\mathrm{b}}$ Number of specimens

\begin{tabular}{|c|c|c|c|c|c|c|c|c|}
\hline Study & TP & & $\mathrm{FN}$ & TN & Sensitivity (95\% Cl) & Specificity $(95 \%$ Cl) & Sensitivity $(95 \% \mathrm{Cl})$ & Specificity (95\% CI) \\
\hline Albuquerque 2014 & 42 & 5 & 1 & 98 & $0.98[0.88,1.00]$ & $0.95[0.89,0.98]$ & $\rightarrow$ & 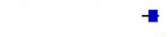 \\
\hline Antonenka & 48 & 0 & 17 & 51 & $0.74[0.61,0.84]$ & $1.00[0.93,1,00]$ & & \\
\hline Armand 2011 & 31 & 0 & 6 & 33 & $0.84[0.68,0.94]$ & $1.00[0.89,1.00]$ & & $\rightarrow$ \\
\hline Barletta 2014 & 79 & 1 & 5 & 33 & $0.94[0.87,0.98]$ & $0.97[0.85,1,00]$ & & $\rightarrow$ \\
\hline Bloemberg 2013 & 61 & 9 & 8 & 751 & $0.88[0.78,0.95]$ & $0.99[0.98,0.99]$ & & \\
\hline Chadran 2010 & 35 & 1 & 0 & 36 & $1.00[0.90,1.00]$ & $0.97[0.86,1.00]$ & $\rightarrow$ & $\rightarrow$ \\
\hline Chang 2015 & 255 & 491 & 1782 & 2377 & $0.59[0.54,0.64]$ & $0.98[0.97,0.99]$ & - & \\
\hline Chen 2012 & 70 & 0 & 6 & 102 & $0.92[0.84,0.97]$ & $1.00[0.96,1.00]$ & & \\
\hline Cho 2015 & 122 & 35 & 502 & 2177 & $0.71[0.64,0.78]$ & $0.98[0.98,0.99]$ & & \\
\hline Choi 2013 & 38 & 0 & 9 & 572 & $0.81[0.67,0.91]$ & $1.00[0.99,1.00]$ & & \\
\hline Feizabadi 2013 & 101 & 11 & 3 & 132 & $0.97[0.92,0.99]$ & $0.92[0.87,0.96]$ & & \\
\hline Hofmann-Thiel 2016 & 233 & 2 & 0 & 480 & $1.00[0.98,1,00]$ & $1.00[0.99,1,00]$ & & \\
\hline Huh 2015 & 180 & 32 & 896 & 6471 & $0.67[0.61,0.73]$ & $1.00[0.99,1.00]$ & & \\
\hline $\ln 2014$ & 63 & 10 & 12 & 162 & $0.84[0.74,0.91]$ & $0.94[0.90,0.97]$ & & 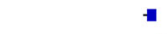 \\
\hline Jonsson 2015 & 173 & 12 & 802 & 2123 & $0.68[0.62,0.74]$ & $0.99[0.99,1.00]$ & 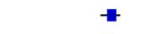 & \\
\hline Kheawon 2012 & 40 & 35 & 21 & 334 & $0.66[0.52,0.77]$ & $0.91[0.87,0.93]$ & $\rightarrow-$ & - \\
\hline Kim 2011 & 19 & 3 & 5 & 65 & $0.79[0.58,0.93]$ & $0.96[0.88,0.99]$ & $\longrightarrow$ & $\rightarrow$ \\
\hline Lee 2010 & 21 & 5 & 6 & 67 & $0.78[0.58,0.91]$ & $0.93[0.85,0.98]$ & $\rightarrow-$ & $\rightarrow$ \\
\hline Lee 2013 & 183 & 13 & 38 & 353 & $0.83[0.77,0.88]$ & $0.96[0.94,0.98]$ & 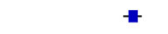 & - \\
\hline $\operatorname{Lim} 2014$ & 81 & 21 & 71 & 1058 & $0.92[0.84,0.97]$ & $0.98[0.97,0.99]$ & & \\
\hline Lira 2013 & 53 & 5 & 13 & 94 & $0.80[0.69,0.89]$ & $0.95[0.89,0.98]$ & $\rightarrow$ & 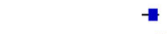 \\
\hline Mangat 2016 & 52 & 0 & 3 & 19 & $0.95[0.85,0.99]$ & $1.00[0.82,1.00]$ & & $\rightarrow$ \\
\hline Miller 2011 & 29 & 3 & 2 & 55 & $0.94[0.79,0.99]$ & $0.95[0.86,0.99]$ & $\rightarrow$ & $\rightarrow$ \\
\hline Park 2013 & 20 & 6 & 8 & 286 & $0.71[0.51,0.87]$ & $0.98[0.96,0.99]$ & - & \\
\hline Pinhata 2015 & 56 & $g$ & 6 & 644 & $0.90[0.80,0.96]$ & $0.99[0.97,0.99]$ & $\rightarrow$ & I \\
\hline Rachow 2011 & 62 & 2 & 8 & 220 & $0.89[0.79,0.95]$ & $0.99[0.97,1.00]$ & & \\
\hline Sethi 2012 & 27 & 2 & 10 & 11 & $0.73[0.56,0.86]$ & $0.85[0.55,0.98]$ & & \\
\hline Sharma 2015 & 465 & 0 & 01 & 1015 & $1.00[0.99,1.00]$ & $1.00[1.00,1.00]$ & & \\
\hline Tortoli 2012 & 158 & 2 & 374 & 4143 & $0.81[0.75,0.86]$ & $1.00[1.00,1.00]$ & & \\
\hline Wang 2013 & 7 & 0 & 7 & 16 & $0.50[0.23,0.77]$ & $1.00[0.79,1.00]$ & & \\
\hline Yang 2011 & 129 & & 12 & 940 & $0.91[0.86,0.96]$ & $0.99[0.98,0.99]$ & & 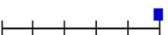 \\
\hline
\end{tabular}

Fig. 4 Forest plot of estimates of RT-PCR assay for pulmonary tuberculosis (PTB). TP = true positive, FP = false positive, $F N=$ false negative, $T N=$ true negative. Between brackets are the $95 \% \mathrm{Cl}$ of sensitivity and specificity. The figure shows the estimated sensitivity and specificity of the study (blue squares) and its $95 \% \mathrm{Cl}$ (black horizontal line) 


\begin{tabular}{|c|c|c|c|c|c|c|c|}
\hline Study & & FP FN & TN & Sensitivity (95\% Cl) & Specificity (95\% Cl) & Sensitivity (95\% Cl) & Specificity (95\% Cl) \\
\hline Armand 2011 & 13 & 04 & 30 & $0.76[0.50,0.93]$ & $1.00[0.88,1.00]$ & $\longrightarrow$ & $\rightarrow$ \\
\hline emberg 2013 & 14 & 148 & 244 & $0.64[0.41,0.83]$ & $0.95[0.91,0.97]$ & $\longrightarrow$ & - \\
\hline usse 2011 & 32 & 59 & 294 & $0.78[0.62,0.89]$ & $0.98[0.96,0.99]$ & $\rightarrow$ & 1 \\
\hline aidir 2012 & 95 & 045 & 67 & $0.68[0.59,0.75]$ & $1.00[0.95,1.00]$ & $\#$ & 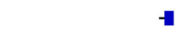 \\
\hline itris 2010 & 86 & 146 & 71 & $0.65[0.56,0.73]$ & $0.99[0.93,1.00]$ & & - \\
\hline 02015 & 6 & 812 & 600 & $0.33[0.13,0.59]$ & $0.99[0.97,0.99]$ & $\rightarrow-$ & - \\
\hline oe 2011 & 47 & 116 & 65 & $0.75[0.62,0.85]$ & $0.98[0.92,1.00]$ & & -1 \\
\hline oi 2013 & 8 & 02 & 55 & $0.80[0.44,0.97]$ & $1.00[0.94,1.00]$ & $\rightarrow$ & -1 \\
\hline yal 2010 & 45 & 01 & 1 & $0.98[0.88,1.00]$ & $1.00[0.03,1.00]$ & $\rightarrow$ & \\
\hline Khechine 2009 & 28 & 30 & 103 & $1.00[0.88,1.00]$ & $0.97[0.92,0.99]$ & $\rightarrow$ & 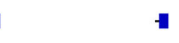 \\
\hline edrich 2011 & 5 & 015 & 5 & $0.25[0.09,0.49]$ & $1.00[0.48,1.00]$ & 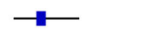 & \\
\hline Us 2012 & 16 & 29 & 12 & $0.64[0.43,0.82]$ & $0.86[0.57,0.98]$ & $\longrightarrow$ & \\
\hline Iemann $20^{\circ}$ & 35 & 910 & 467 & $0.78[0.63,0.89]$ & $6,0.99]$ & 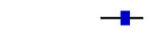 & - \\
\hline fmantr-Thiel 2016 & 90 & 00 & 17 & $1.00[0.96,1.00]$ & $1.00[0.80,1.00]$ & 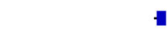 & $\rightarrow$ \\
\hline Isson 2015 & 65 & 963 & 868 & $0.51[0.42,0.60]$ & $0.99[0.98,1,00]$ & - & - \\
\hline 2011 & 1 & 03 & 289 & $0.25[0.01,0.81]$ & $1.00[0.99,1.00]$ & & \\
\hline $2010 \mathrm{a}$ & 21 & 019 & 96 & $0.53[0.36,0.68]$ & $1.00[0.96,1.00]$ & - & \\
\hline asmita 2012 & 23 & 46 & 40 & $0.79[0.60,0.92]$ & $0.91[0.78,0.97]$ & & 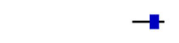 \\
\hline 02010 & 10 & 09 & 51 & $0.53[0.29,0.76]$ & $1.00[0.93,1.00]$ & $\because-$ & $\rightarrow$ \\
\hline Ihotra 2012 & 132 & 08 & 415 & $9,0.98]$ & $1.00[0.99$ & & \\
\hline ler 2 & 5 & 21 & 15 & $0.83[0.36,1.00]$ & 0.88[ & & \\
\hline ure 2 & 37 & 026 & 86 & $0.59[0$ & $1.00[0.96,1.00]$ & $\rightarrow$ & \\
\hline 800 & 42 & 356 & 49 & $0.43[0.33,0.53]$ & $0.94[0.84,0.99]$ & $\rightarrow$ & $\rightarrow$ \\
\hline & 11 & 00 & 11 & 1.00 & & & $\longrightarrow$ \\
\hline oli 2012 & 36 & 220 & 1669 & $0.64[0.50,0.77]$ & $1.00[1.00,1.00]$ & 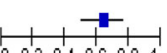 & \\
\hline
\end{tabular}

Fig. 5 Forest plot of estimates of RT-PCR assay for extra-pulmonary tuberculosis (EPTB). TP = true positive, FP = false positive, $F N=$ false negative, TN $=$ true negative. Between brackets are the $95 \% \mathrm{Cl}$ of sensitivity and specificity. The figure shows the estimated sensitivity and specificity of the study (blue squares) and its 95\% Cl (black horizontal line)

Table 3 Subgroup analyses by RT-PCR assay type

\begin{tabular}{|c|c|c|c|c|}
\hline \multirow[t]{2}{*}{ RT-PCR assay type } & \multirow{2}{*}{$\begin{array}{l}\text { Summary measure of } \\
\text { test accuracy }{ }^{a}(95 \% \\
\text { Cl) }\end{array}$} & \multicolumn{3}{|c|}{ Test for heterogeneity } \\
\hline & & $\left(x^{2}\right)(d f=24)$ & $\left(1^{2}\right)$ & $\overline{p \text { value }}$ \\
\hline \multicolumn{5}{|c|}{ CobasTaqMan $\left(n=17 ;{ }^{\text {b}} 19,814\right)$ AUC $=0.98$} \\
\hline Sensitivity & $0.78(0.76-0.80)$ & 205.13 & $92.20 \%$ & $<0.001$ \\
\hline Specificity & $0.99(0.99-0.99)$ & 127.21 & $87.40 \%$ & $<0.001$ \\
\hline Positive likelihood ratio (PLR) & 41.59 (27.80-62.18) & 98.14 & $83.70 \%$ & $<0.001$ \\
\hline Negative likelihood ratio (NLR) & $0.18(0.13-0.23)$ & 134.36 & $88.10 \%$ & $<0.001$ \\
\hline Diagnostic odds ratio (DOR) & 273.14 (181.45-411.17) & 47.6 & $66.40 \%$ & $<0.001$ \\
\hline \multicolumn{5}{|c|}{ Light Cycler $\left(n=7 ;{ }^{b} 1159\right)$ AUC $=0.97$} \\
\hline Sensitivity & $0.85(0.80-0.88)$ & 61.71 & $90.30 \%$ & $<0.001$ \\
\hline Specificity & $0.99(0.98-0.99)$ & 10.09 & $40.50 \%$ & 0.121 \\
\hline Positive likelihood ratio (PLR) & $21.65(6.82-68.72)$ & 17.45 & $65.60 \%$ & 0.008 \\
\hline Negative likelihood ratio (NLR) & $0.17(0.08-0.38)$ & 63.77 & $90.60 \%$ & $<0.001$ \\
\hline Diagnostic odds ratio (DOR) & 150.52 (31.97-708.78) & 20.35 & $70.50 \%$ & $<0.002$ \\
\hline \multicolumn{5}{|c|}{ Cepheid and others $\left(n=22 ;{ }^{b} 14,839\right)$ AUC $=0.99$} \\
\hline Sensitivity & $0.78(0.77-0.80)$ & 729.43 & $97.10 \%$ & $<0.001$ \\
\hline Specificity & $0.99(0.99-0.99)$ & 299.13 & $93.00 \%$ & $<0.001$ \\
\hline Positive likelihood ratio (PLR) & $38.50(19.65-75.42)$ & 234.62 & $91.00 \%$ & $<0.001$ \\
\hline Negative likelihood ratio (NLR) & $0.22(0.15-0.33)$ & 594.30 & $96.50 \%$ & $<0.001$ \\
\hline Diagnostic odds ratio (DOR) & $221.44(94.94-516.51)$ & 208.25 & $89.90 \%$ & $<0.001$ \\
\hline
\end{tabular}

$x^{2}$ chi-squared, $d f$ degree of freedom, $l^{2}$ I-squared, $n$ number of studies, $C l$ confidence interval, $A U C$ area under receiver operating characteristics curve

${ }^{\text {a}}$ Random-effects model

${ }^{\mathrm{b}}$ Number of specimens 
heterogeneity. The results for subgroup analysis by RT-PCR assay target sequence gene are presented in Table 4 and Additional file 5 and show considerable heterogeneity.

III.With other genes (see Table 1) as the RT-PCR assay (17 studies, 11,870 specimens) the results were as follows: sensitivity 0.82 (0.80-0.84), specificity 0.99 (0.99-0.99) and AUC 0.98. A test with perfect discrimination has a ROC curve that passes through the upper left corner (100\% sensitivity, $100 \%$ specificity). The closer the ROC curve to the upper left corner, the higher the overall accuracy of the test. The summary estimates of other genes heterogeneity with chi-squared $\left(\chi^{2}\right)$ using 95\% CI for sensitivity, specificity, PLR, NLR and DOR were 413.02, 173.35, 123.92, 498.03 and 125.08 , respectively, and $p<0.001$ indicating significant heterogeneity across studies. $I^{2}$ was between 87.20 and $96.10 \%$ showing significant heterogeneity. The results for subgroup analysis by RT-PCR assay target sequence gene are presented in Table 4 and Additional file 5 and show considerable heterogeneity.

\section{Discussion}

Tuberculosis is a global health threat and early and accurate diagnosis is crucial for preventing morbidity and mortality. Various methods are employed for the diagnosis of TB such as smear microscopy, culture identification, histopathology, tuberculin skin test (TST), serological assays, interferon-gamma release assays (IGRAs) and nucleic acid amplification (NAA) tests [68, 69]. Smear microscopy is widely used in the diagnosis of TB but has drawbacks owing to low and variable sensitivity values (0$40 \%)$ and cannot readily differentiate between MTB and non-tuberculous mycobacteria (NTM) [70-72]. Culture identification for MTB also has variable sensitivities (0$80 \%)$ in different TB specimens [63, 73-75] with turn-around time of $2-10$ weeks requiring the use of skilful technicians [76]. Diagnosis of TB from tissue samples is usually made by histopathological examination that depends on the presence of granulomatous inflammation and caseous necrosis [70,77]. However, histology does not distinguish between EPTB and infections from other granulomatous diseases such as NTM, sarcoidosis, leprosy and systemic lupus erythematosus (except for the presence of acid-fast bacilli (AFB)) [78, 79]. RT-PCR is a novel

Table 4 Subgroup analyses by RT-PCR assay target sequence gene

\begin{tabular}{|c|c|c|c|c|}
\hline \multirow[t]{2}{*}{ RT-PCR assay genes } & \multirow{2}{*}{$\begin{array}{l}\text { Summary measure of } \\
\text { test accuracy }{ }^{\mathrm{a}}(95 \% \\
\text { Cl) }\end{array}$} & \multicolumn{3}{|c|}{ Test for heterogeneity } \\
\hline & & $\left(x^{2}\right)(d f=24)$ & $\left(l^{2}\right)$ & $\overline{p \text { value }}$ \\
\hline \multicolumn{5}{|l|}{ IS6110 $\left(n=22 ;{ }^{b} 12,004\right)$ AUC $=0.99$} \\
\hline Sensitivity & $0.79(0.77-0.81)$ & 470.30 & $95.50 \%$ & $<0.001$ \\
\hline Specificity & $0.98(0.98-0.98)$ & 150.16 & $86.00 \%$ & $<0.001$ \\
\hline Positive likelihood ratio (PLR) & $31.76(20.12-50.13)$ & 134.64 & $84.40 \%$ & $<0.001$ \\
\hline Negative likelihood ratio (NLR) & $0.17(0.12-0.24)$ & 356.22 & $94.10 \%$ & $<0.001$ \\
\hline Diagnostic odds ratio (DOR) & $243.69(127.07-437.37)$ & 141.04 & $85.10 \%$ & $<0.001$ \\
\hline \multicolumn{5}{|l|}{$16 \mathrm{~S}$ rRNA $\left(n=7 ;{ }^{\mathrm{b}} 12,074\right) \mathrm{AUC}=0.97$} \\
\hline Sensitivity & $0.69(0.66-0.72)$ & 45.85 & $86.90 \%$ & $<0.001$ \\
\hline Specificity & $0.99(0.99-0.99)$ & 32.10 & $81.30 \%$ & $<0.001$ \\
\hline Positive likelihood ratio (PLR) & $67.64(36.40-125.70)$ & 34.60 & $82.50 \%$ & $<0.001$ \\
\hline Negative likelihood ratio (NLR) & $0.29(0.24-0.36)$ & 19.87 & $69.8 \%$ & 0.003 \\
\hline Diagnostic odds ratio (DOR) & $287.19(193.85-425.46)$ & 9.12 & $34.20 \%$ & 0.167 \\
\hline \multicolumn{5}{|c|}{ Other genes $\left(n=17 ;{ }^{b} 11,870\right)$ AUC $=0.98$} \\
\hline Sensitivity & $0.82(0.80-0.84)$ & 413.02 & $96.10 \%$ & $<0.001$ \\
\hline Specificity & $0.99(0.99-0.99)$ & 173.35 & $90.80 \%$ & $<0.001$ \\
\hline Positive likelihood ratio (PLR) & $42.48(20.66-87.36)$ & 123.92 & $87.10 \%$ & $<0.001$ \\
\hline Negative likelihood ratio (NLR) & $0.22(0.13-0.37)$ & 498.03 & $96.80 \%$ & $<0.001$ \\
\hline Diagnostic odds ratio (DOR) & $234.56(86.01-639.63)$ & 125.08 & $87.20 \%$ & $<0.001$ \\
\hline
\end{tabular}

$x^{2}$ chi-squared, $d f$ degree of freedom, $l^{2}$ I-squared, $n$ number of studies, $C I$ confidence interval, AUC area under receiver operating characteristics curve, IS6110 Mycobacterium tuberculosis complex-specific insertion sequence, 16S rRNA 16S ribosomal RNA gene of MTB, Other genes rpoB as target sequence, mpt64 gene, 81bp rpoB gene, senX3-regX3 intergenic region, 61 genomic DNA (gDNA) samples of MTB, cytochrome P450 Cyp 141 gene

${ }^{\text {a Random-effects model }}$

${ }^{b}$ Number of specimen 
and robust assay primarily used to quantify the nucleic acids in all TB specimens [63, 80-82]. The main advantages of RT-PCR are shortened turn-a-round time, quantification of bacterial load and automation of the procedure that reduces hands-on time and decreased risk of crosscontamination $[63,83]$. This review provides evidence on the effectiveness of RT-PCR assay for the rapid and accurate detection of MTB from pathological samples. To our knowledge, this is the first systematic review and metaanalysis for ascertaining the effectiveness of RT-PCR assays for the detection of MTB from both pulmonary and extra-pulmonary pathological samples.

In this study, results indicated that RT-PCR assay produces consistent results with high specificity of 0.99 (95\% CI 0.99-0.99), PLR of 43.0 (28.23-64.81) and NLR of $0.16(0.12-0.20)$ for PTB, whereas specificity, PLR and NLR were 0.99 (95\% CI, 0.99-0.99), 29.82 (17.8649.78) and 0.33 (0.26-0.42), respectively, for EPTB. A PLR of 43 suggests that patients with a pulmonary MTB infection have a 43-fold higher chance of being RT-PCR test positive compared with patients without the infection. This ratio suggests a potential role for RT-PCR assay in confirming (ruling in) a MTB infection.

The summary estimates of sensitivity, however, were 0.82 (95\% CI $0.81-0.83$ ) and 0.70 (95\% CI 0.67-0.72) for pulmonary and extra-pulmonary samples, respectively, higher in pulmonary than extra-pulmonary $\mathrm{TB}$ possibly due to paucity of tubercle bacilli in extra-pulmonary samples. Sensitivity estimates were more variable than specificity. According to the AUC and the DOR (see Table 2), diagnostic accuracy of RT-PCR assay was excellent for the pulmonary specimens over extra-pulmonary and these results are acceptable for clinical practice (see Table 2).

A RT-PCR assay for the detection of MTB has a high sensitivity and specificity. The PLR and NLR showed that RT-PCR may serve as a suitable method when confirming or excluding TB. It was anticipated that there would be some degree of heterogeneity of diagnostic measures across studies due to differences in sample size, RT-PCR assay type, reference test (either liquid or solid or both) and TB prevalence. High heterogeneity was found among studies (as defined by the $\chi^{2}$ and $I^{2}$ statistics) for all measures. Subgroup analyses were therefore performed pre-specified to investigate potential sources of the observed between-study heterogeneity. It was assumed that the disparity was likely a result of the differences in the type of index test (RT-PCR assay) or target sequence gene of MTB used.

In the current study, a limited number of subgroup analyses were conducted by comparing CobasTaqMan, Light Cycler, Cepheid and others as RT-PCR assay types to reduce the degree of study heterogeneity. Heterogeneity assessed by $X^{2}$ and $I^{2}$ statistics between these subgroups was generally not very strong (see Table 3 ). However, significant heterogeneity of diagnostic accuracy measures was expected and was, indeed, found among studies and the random-effects model partially accounted for the between-study heterogeneity.

Some degree of heterogeneity of diagnostic measures across studies was found due to differences in sample size, study design, target genes and clinical settings of the participants. Thus, it is possible that when evaluating RT-PCR assays using a more sensitive index test can lead to overestimation of the assay's sensitivity. No significant differences in specificities of the different types of index tests were observed.

\section{Strengths and weaknesses of the review}

An important strength of this study was its comprehensive search strategy using several search engines to identify any unpublished studies in the form of conference abstracts or proceedings. Screening, study selection, quality assessment and data extraction were undertaken independently and reproducibly by two reviewers, as such human error should be limited. The problem of missing data was reduced by contacting the authors of the publications. In accordance with the study guidelines, potential publication bias and heterogeneity was explored [15, 84]. Evaluation of level of publication bias was not formally carried out in the study; however, the risk of this bias was reduced by not restricting the search to any language. In addition, we contacted experts for information on additional studies. Another strength of this review is that RT-PCR assay has comparably high sensitivity with paucibacillary specimens and high throughput capacities.

This review does, however, have some limitations in assessing issues such as cost-effectiveness and the net effect of RT-PCR assay on clinical care and patient outcomes. Also, because of poor reporting, an analysis of the effect of factors such as laboratory infrastructure was not possible. Secondly, empirical evidence suggests that studies with significant or favourable results are more likely to be published than those with non-significant or unfavourable results [85]. In addition, literature search strategies are inherently imperfect and studies can be missed, it is therefore possible that a proportion of such studies with non-significant or unfavourable results may have been missed. Other limitations are conflicts of interest of study authors particularly from industry supported studies and fully keeping up to date with the primary studies in this rapidly evolving field.

Given that RT-PCR assays in this review cover a wide range of different target genes and procedures, it is not possible to recommend any one over another owing to a lack of direct test comparisons. Our findings should be interpreted in the context of the quality of studies and 
reporting and variability in study quality. Diagnostic studies in general [86] and TB diagnostic studies in particular [87] seem to be beset by these problems.

\section{Implications for research and clinical practice}

Current evidence suggests a potential role for RT-PCR assay in confirming a diagnosis of TB. It offers an alternative robust approach to detect MTB in paucibacillary EPTB samples that provides rapid results with good diagnostic accuracy. The results of this assay type should be interpreted in parallel with clinical findings and the results of conventional tests; but the assay contributes significantly for an early diagnosis and exerts an impact on clinical management and control of TB. Our findings do not support the use of this assay type for excluding diagnosis of tuberculosis as standalone test.

For EPTB, clinical judgement has both poor sensitivity and specificity. The NICE guidelines recommend the use of culture, histology and/or chest X-ray for patients with non-respiratory TB [88]. Consequently, outcomes of a negative smear for acid-fast bacilli, lack of granulomas on histopathology and failure to culture MTB do not exclude the diagnosis of EPTB; RT-PCR assay has proved to be a novel diagnostic modality in varied forms of EPTB. This review suggests RT-PCR assay can be of help as a most specific test in a 'rule-in decision' for MTB detection.

The reliability of RT-PCR to confirm an early diagnosis of TB meningitis and abdominal TB has been well established when smear and culture tests are rarely positive $[89,90]$. It has also proved useful for an early diagnosis of osteoarticular TB in tissue samples and that can help to start timely, appropriate anti-tubercular therapy (ATT) [91] and prevent progression to irreversible tissue changes. Due to small sample volumes available, irregular dispersion of MTB in specimens both viable and non-viable, RT-PCR has aided in detecting MTB compared with conventional tests from an array of different cases of EPTB such as pericardial tuberculosis, disseminated/miliary tuberculosis, thyroid tuberculosis, ocular tuberculosis, tuberculous mastitis and others [90].

Future studies should compare commercialised RTPCR assays to determine their diagnostic accuracy. The use of guidelines such as the Standards for Reporting of Diagnostic Accuracy (STARD) might improve the quality of reporting of primary studies [92]. Further work is required to devise a simple and cost-effective RT-PCR test for an efficient diagnosis of TB that can be used routinely in resource-poor countries.

\section{Conclusion}

According to this review and meta-analysis, RT-PCR assay has a high sensitivity and specificity for PTB with turn-a-round time of $2 \mathrm{~h}$ compared with reference culture-based assay that takes between 2 and 10 weeks for detection. Overall, RT-PCR assay accuracy was superior for pulmonary samples (sensitivity 0.82 (95\% CI 0.81-0.83); specificity 0.99 (95\% CI $0.99-0.99)$ ) as opposed to extra-pulmonary samples (sensitivity 0.70 (95\% CI $0.67-0.72$ ); specificity 0.99 (95\% CI $0.99-0.99)$ ) possibly due to paucibacillary. The specificity was high for both pulmonary and extra-pulmonary samples indicating that the test should be adopted as the first-line test for ruling in TB infection but may need to be an add-on test to rule out the disease. It offers an alternative robust approach to detect MTB in paucibacillary EPTB samples, showing rapid results with good diagnostic accuracy. The results of this assay should be interpreted in parallel with clinical findings and the results of conventional tests, but the assay may contribute significantly for an early diagnosis and exert an impact on the clinical management and control of TB. The findings do not support the use of this assay for excluding a diagnosis of $\mathrm{TB}$ on its own as a standalone test. It offers an incremental benefit as an add-on test to other investigations. RTPCR assays, combining amplification and detection in a single run, seem to offer advantages over conventional assays including the reference standard.

From the data of investigations of heterogeneity, factors such as RT-PCR assay types (CobasTaqMan, Light Cycler, Cepheid and others) and RT-PCR assay target sequence genes (IS6110, 16SRNA and other genes) were considered to have influenced the accuracy estimates.

It is anticipated that our findings will aid healthcare practitioners and policymakers in adopting the use of this assay on a routine basis. Most importantly, this can be as a point-of-care-test which will help in the global control of MTB, particularly in developing countries with a high burden of the disease.

\section{Additional files}

\footnotetext{
Additional file 1: PRISMA checklist. (DOCX $17 \mathrm{~kb}$ )

Additional file 2: Search strategy. (DOC $28 \mathrm{~kb}$ )

Additional file 3: Quality assessment of diagnostic accuracy. (DOC $49 \mathrm{~kb}$ )

Additional file 4: Definition of statistical parameters. (DOC $39 \mathrm{~kb}$ )

Additional file 5: Figures of Subgroup analyses. (DOC $1822 \mathrm{~kb}$ )
}

\section{Abbreviations}

ATT: Anti-tubercular therapy; CIDG SR: Cochrane Infectious Diseases Group Specialised Register; CPCI-S: Conference Proceedings Citation Index- Science; DNA: Deoxyribonucleic acid; EPTB: Extra-pulmonary tuberculosis; HIV: Human immunodeficiency virus; IGRAs: Interferon-Gamma Release Assays; IUALTD: International Union Against Tuberculosis and Lung Disease; MTB: Mycobacterium tuberculosis; NAATs: Nucleic Acid Amplification Tests; NICE: National Institute for Health and Care Excellence; PRISMA: Preferred Reporting Items for Systematic Reviews and Meta-Analyses; PTB: Pulmonary tuberculosis; QUADAS-2: Quality Assessment of Diagnostic Accuracy Studies2; RT-PCR: Real-time polymerase chain reaction; STARD: Standards for Reporting of Diagnostic Accuracy; TB: Tuberculosis; TRIP: Turning research into practice; TST: Tuberculin skin test; WHO: World Health Organization 


\section{Acknowledgements}

$E B$ is not funded.

$B C$ is not funded.

LB is not funded.

GM is not funded.

$\mathrm{KN}$ is not funded.

We are grateful to the authors of the primary studies who responded to our request for additional information.

\section{Funding}

None

\section{Authors' contributions}

EB formulated the research question and designed the study. EB developed the search strategy. EB and BC drafted the manuscript. LB and GM critically reviewed the manuscript for content. KN reviewed the statistical analysis. All authors have approved the final version of the manuscript.

\section{Authors' information}

EB is a Senior Biomedical Scientist.

$B C$ is a Consultant Microbiologist.

$L B$ is a Senior Lecturer in Medicinal Chemistry.

GM is a Professor of Chemistry.

KN is a Medical Statistician.

\section{Ethics approval and consent to participate \\ N/A}

\section{Consent for publication}

N/A

\section{Competing interests}

The authors declare that they have no competing interests.

\section{Publisher's Note}

Springer Nature remains neutral with regard to jurisdictional claims in published maps and institutional affiliations.

\section{Author details}

'Microbiology Department, Pathology Division, Sandwell and West Birmingham Hospitals NHS Trust, Birmingham, UK. ${ }^{2}$ Microbiology Department, Bart's Health NHS Trust, London, UK. ${ }^{3}$ School of Pharmacy and Biomedical Sciences, University of Portsmouth, Portsmouth, UK. ${ }^{4}$ School of Health Sciences and Social Work, University of Portsmouth, Portsmouth, UK.

Received: 4 May 2017 Accepted: 12 October 2017

Published online: 25 October 2017

\section{References}

1. Wallis RS, Pai M, Menzies D, Doherty TM, Walz G, Parkins MD, et al. Biomarkers and diagnostics for tuberculosis: progress, needs and translation into practice. Lancet. 2010;375:1920-37.

2. Al-Ateah SM, Al-Dowaidi MM, El-Khizzi N. Evaluation of direct detection of Mycobacterium tuberculosis complex in respiratory and non-respiratory clinical specimens using the Cepheid Gene Xpert system. Saudi Med J. 2012:33:1100-5.

3. Nikam C, Jagannath M, Narayanan MM, Ramanabhiraman V, Kazi M, Shetty A, et al. Rapid diagnosis of Mycobacterium tuberculosis with Truenat MTB: a near-care approach. PLoS One. 2013;8:e51121.

4. World Tuberculosis Day 2016: Unite to End Tuberculosis. http://www.afro. who.int/en/clusters-a-programmes/dpc/tuberculosis/world-tuberculosis-day. html. Accessed 13 Dec 2016.

5. WHO Tuberculosis Global Report 2016. http://www.who.int/tb/Global_TB_ Facts.pdf?ua=1. Accessed: 18 Oct 2016.

6. Public Health England Tuberculosis in England: 2016 report (presenting data to end of 2015). https://www.gov.uk/government/uploads/system/ uploads/attachment_data/file/564656/TB_annual_report_2016.pdf Accessed 19 Dec 2016.

7. European Centre for Disease Prevention and Control. World Health Organization Regional Office Europe. Tuberculosis surveillance in Europe
2009. Stockholm: European Centre for Disease Prevention and Control; 2011

8. de Catalunya G. Informe anual. Situació epidemiológicai tendencia de l'endèmia tuberculosa a Catalunya. Barcelona: Departament de Salut; 2009. http://www.gencat.cat/salut/depsalut/html/ca/dir2474/inf2009tuber.pdf. Accessed 23 Oct 2015

9. White S, Schultz T, Enuameh YAK. Synthesizing evidence of diagnostic accuracy. Philadelphia: Lippincott Williams \& Wilkins; 2011.

10. Espy MJ, Uhl JR, Sloan LM, Buckwalter SP, Jones MF, Vetter EA, et al. Realtime PCR in clinical microbiology: applications for routine laboratory testing. Clin Microbiol Rev. 2006;19:192-4.

11. Rachow A, Zumla A, Heinrich N, Rojas-Ponce G, Mtafya B, Reither K, et al. Rapid and accurate detection of Mycobacterium tuberculosis in sputum samples by Cepheid Xpert MTB/RIF assay-a clinical validation study. PLoS One. 2011;6:e20458. https://doi.org/10.1371/journal.pone.0020458.

12. Moher D, Liberati A, Tetzlaff J, Altman DG, The PRISMA Group. Preferred reporting items for systematic reviews and meta-analyses: the PRISMA statement. PLoS Med. 2009;6(7):e1000097. https://doi.org/10.1371/journal. pmed1000097.

13. Whiting PF, Rutjes AW, Westwood ME, Mallett S, Deeks JJ, Reitsma JB, Leeflang MM, Sterne JA, Bossuyt PM. QUADAS-2: a revised tool for the quality assessment of diagnostic accuracy studies. Ann Intern Med. 2011;155:529-36.

14. Dickersin K. Publication bias: recognizing the problem, understanding its origins and scope, and preventing harm. In: Rothstein HR, Sutton AJ, Borenstein $\mathrm{M}$, editors. Publication bias in meta-analysis: prevention, assessment and adjustments. Chichester: Wiley; 2005. p. 11-33.

15. Deville WL, Buntinx F, Bouter LM, Montori VM, de Vet HC, van der Windt DA, et al. Conducting systematic reviews of diagnostic studies: didactic guidelines. BMC Med Res Methodol. 2002;2:9-12.

16. Irwig L, Macaskill P, Glasziou P, Fahey M. Meta-analytic methods for diagnostic test accuracy. J Clin Epidemiol. 1995;48:119-30.

17. Deeks JJ. Systematic reviews of evaluations of diagnostic and screening tests. In: Egger M, Smith GD, Altman DG, editors. Systematic reviews in health care. Meta-analysis in context, vol. 323. London: BMJ Publishing Group; 2001. p. 248-82.

18. Zamora J, Abraira V, Muriel A, Khan K, Coomarasamy A. Meta-DiSc: a software for meta-analysis of test accuracy data. BMC Med Res Methodol. 2006:6:31-42.

19. DerSimonian R, Laird N. Meta-analysis in clinical trials. Control Clin Trials. 1986;7:177-88.

20. Leeflang MM, Deeks JJ, Takwoingi Y, Macaskill P. Cochrane diagnostic test accuracy reviews. Syst Rev. 2013;2:82-7.

21. Lijmer JG, Bossuyt PM, Heisterkamp SH. Exploring sources of heterogeneity in systematic reviews of diagnostic tests. Stat Med. 2002;21:1525-37.

22. Higgins JP, Green S. Cochrane handbook for systematic reviews of interventions. Available from http://handbook-5-1.cochrane.org/.

23. Causse M, Ruiz P, Gutiérrez Aroca JB, Casal M. Comparison of two molecular methods for rapid diagnosis of extrapulmonary tuberculosis. J Clin Microbiol. 2011:49:3065-7.

24. Albuquerque YMM, Lima ALMA, Lins AK, Magalhães M, Magalhães V. Quantitative real-time PCR (q-PCR) for sputum smear diagnosis of pulmonary tuberculosis among people with HIV/AIDS. Rev Inst Med Trop Sao Paulo. 2014:56:139-42.

25. Antonenka U, Hofmann-Thiel S, Turaev L, Esenalieva A, Abdulloeva M, et al. Comparison of Xpert MTB/RIF with ProbeTec ET DTB and COBAS TaqMan MTB for direct detection of $M$. tuberculosis complex in respiratory specimens. BMC Infect Dis. 2013;13:280-5.

26. Armand S, Vanhuls P, Delcroix G, Courcol R, Lemaitre N. Comparison of the Xpert MTB/RIF test with an IS6110-TaqMan real-time PCR assay for direct detection of Mycobacterium tuberculosis in respiratory and nonrespiratory specimens. J Clin Microbiol. 2011:49:1772-6.

27. Barletta F, Vandelannoote K, Collantes J, Evans CA, Arévalo J, Rigouts L. Standardization of a TaqMan-based real-time PCR for the detection of Mycobacterium tuberculosis-complex in human sputum. Am Soc Trop Med Hyg. 2014;91:709-14.

28. Bloemberg GV, Voit A, Ritter C, Deggim V, Böttger EC. Evaluation of COBAS(R) TaqMan MTB for direct detection of Mycobacterium tuberculosis complex in comparison with the COBAS(R) Amplicor MTB. J Clin Microbiol. 2013;51:2112-7.

29. Chaidir L, Ganiem AR, van der Zanden A, Muhsinin S, Kusumaningrum T, Kusumadewi I, et al. Comparison of real time IS6110-PCR, microscopy, and 
culture for diagnosis of Tuberculous meningitis in a cohort of adult patients in Indonesia. PLoS One. 2012;7:e52001. https://doi.org/10.1371/journal.pone. 0052001.

30. Chang JH, Kim SW, Kim SI, Lee SJ, Lee JH, Ryu YJ, et al. The effectiveness of real-time PCR assay, compared with microbiologic results for the diagnosis of pulmonary tuberculosis. Tuber Respir Dis. 2015;78:1-7.

31. Chandran SP, Kenneth J. Evaluation of Cobas TaqMan real time PCR assay for the diagnosis of Mycobacterium tuberculosis. Indian J Med Res. 2010;132:100-2.

32. Chen $X$, Yang $Q$, Kong $H$, Chen $Y$. Real-time PCR and amplified MTD ${ }^{\circledR}$ for rapid detection of Mycobacterium tuberculosis in pulmonary specimens. Intern J Tuberc Lung Dis. 2012;16:235-9.

33. Chitnis DS, Kalantri Y, Hemvani N. Evaluation of real-time polymerase chain reaction, interferon-gamma, adenosine deaminase, and immunoglobulin $\mathrm{A}$ for the efficient diagnosis of pleural tuberculosis. Intern J Infect Dis. 2010;15: e226-31.

34. Cho WH, Won EJ, Choi HJ, Kee SJ, Shin JH, Ryang DW, et al. Comparison of AdvanSure TB/NTM PCR and COBAS TaqMan MTB PCR for detection of Mycobacterium tuberculosis complex in routine clinical practice. Ann Lab Med. 2015;35:356-61.

35. Choe G, Lee HS, Park KU, Park JO, Chang HE, Song J. Rapid, sensitive, and specific detection of Mycobacterium tuberculosis complex by real-time PCR on paraffin-embedded human tissues. J Molec Diagn. 2011;13:390-4.

36. Choi YJ, Kim JW, Kim HJ, Park JS, Nam HS, Hwangbo Y, et al. Comparison of PNA probe-based real-time PCR and Cobas TaqMan MTB for detection of MTBC. BioChip J. 2013;7:85-8.

37. Dayal R, Senthilkumar P, Katoch VM, Chauhan DS, Yadav NK. Diagnostic value of real-time PCR for neurotuberculosis. Indian Paed. 2010;47:631-2.

38. El Khe'chine A, Henry M, Raoult D, Drancourt M. Detection of Mycobacterium tuberculosis complex organisms in the stools of patients with pulmonary tuberculosis. Microbiol. 2009;155:2384-9.

39. Feizabadi MM, Darban-Sarokhali D, Fooladi AAl, Maleknejad P, Bameri Z, Aflaki $M$, et al. Comparison of smear microscopy, culture, and real-time PCR for quantitative detection of Mycobacterium tuberculosis in clinical respiratory specimens. Scand J Infect Dis. 2013;45:250-5.

40. Friedrich SO, von Groote-Bidlingmaier F, Diacon AH. Xpert MTB/RIF assay for diagnosis of pleural tuberculosis. J Clin Microbiol. 2011;49:4341-2.

41. Gous N, Scott LE, Wong E, Omar T, Venter WDF, Stevens W. Performance of the Roche LightCycler real-time PCR assay for diagnosing extrapulmonary tuberculosis. J Clin Microbiol. 2012;50:2100-3.

42. Hillemann D, Ru"sch-Gerdes S, Boehme C, Richter E. Rapid molecular detection of extrapulmonary tuberculosis by the automated GeneXpert MTB/RIF system. J Clin Microbiol. 2011;49:1202-5.

43. Hofmann-Thiela S, Molodtsov N, Antonenka U, Hoffmann H. Evaluation of the Abbott RealTime MTB and RealTime MTB INH/RIF assays for direct detection of Mycobacterium tuberculosis complex and resistance markers in respiratory and extra-pulmonary specimens. J Clin Microbiol. 2016;54:3022-7

44. Huh HJ, Koh WJ, Song DJ, Ki CS, Lee NY. Evaluation of the Cobas TaqMan MTB test for the detection of Mycobacterium tuberculosis complex according to acid-fast-bacillus smear grades in respiratory specimens. J Clin Microbiol. 2015;53:696-8

45. In KH, Lee SH, Kim SW, Lee S, Kim ES, Kim DJ, et al. Rapid detection of Mycobacterium Tuberculosis using a novel ultrafast Chip-type real-time polymerase chain reaction system. Chest. 2014;146:1319-26.

46. Jönsson B, Lönnermark E, Ridell M. Evaluation of the Cobas TaqMan MTB test for detection of Mycobacterium tuberculosis complex. Infect Dis. 2015;47:231-6.

47. Kheawon N, Chuang-Ngam S, Mitsoongneun S, Peam-Am J, Visalsawadi J. Sensitivity and specificity of real time polymerase chain reaction (RT-PCR) in bronchial washing for diagnostic pulmonary tuberculosis at Maharat Nakhorn Ratchasima Hospital. J Med Assoc Thail. 2012;95:1396-403.

48. Kim JH, Kim YJ, Ki CS, Kim JY, Lee NY. Evaluation of Cobas TaqMan MTB PCR for detection of Mycobacterium tuberculosis. J Clin Microbiol. 2011:49:173-6.

49. Lee JE, Lee BJ, Roh EY, Kim DK, Chung HS, Lee CH. The diagnostic accuracy of tuberculosis real-time polymerase chain reaction analysis of computed tomography-guided bronchial wash samples. Diagn Microbiol Infect Dis. 2011;71:51-6.

50. Lee $\mathrm{JH}$, Min JW, Yoon HI, Park KU, Song JH, Lee CT. Real-time polymerase chain reaction in bronchial aspirate for rapid detection of sputum smear-negative tuberculosis. Intern J Tuberc Lung Dis. 2010;14:852-8.
51. Lee MR, Chung KP, Wang HC, Lin CB, CY Y, Lee JJ, Hsueh RP. Evaluation of the Cobas TaqMan MTB real-time PCR assay for direct detection of Mycobacterium tuberculosis in respiratory specimens. J Med Microbiol. 2013:62:1160-4.

52. Lim J, Kim J, Kim JW, Ihm C, Sohn YH, Cho HJ, et al. Multicenter evaluation of Seegene Anyplex TB PCR for the detection of Mycobacterium tuberculosis in respiratory specimens. J Microbiol Biotechnol. 2014;24:1004-7.

53. Linasmita P, Srisangkaew S, Wongsuk T, Bhongmakapat T, Watcharananan SP. Evaluation of real-time polymerase chain reaction for detection of the $16 \mathrm{~S}$ ribosomal RNA gene of Mycobacterium tuberculosis and the diagnosis of cervical tuberculous lymphadenitis in a country with a high tuberculosis incidence. Clin Infect Dis. 2012;55:313-21.

54. Lira LAS, Santos FCF, Carvalho MSZ, Montenegro RA, Lima JFC, Schindler HC, et al. Evaluation of a IS6110-Taqman real-time PCR assay to detect Mycobacterium tuberculosis in sputum samples of patients with pulmonary TB. J Appl Microbiol. 2013;114:1103-8.

55. Luo RF, Scahill MD, Banaei N. Comparison of single-copy and multicopy real-time PCR targets for detection of Mycobacterium tuberculosis in paraffin-embedded tissue. J Clin Microbiol. 2010;48:2569-70.

56. Malhotra B, Sinha P, Hooja S, Vyas L. Rapid diagnosis of genital tuberculosis by real time polymerase chain reaction. J South Asian Feder Obst Gynae. 2012:4:39-42

57. Mangat D, Singh K, Devi NKP. Comparative evaluation of conventional techniques; MGIT and real time PCR for the diagnosis of Mycobacterium tuberculosis from various clinical samples. Intern J Sci Res. 2016;5:501-4.

58. Miller MB, Popowitch EB, Backlund MG, Ager EPC. Performance of Xpert MTB/RIF RUO assay and IS6110 real-time PCR for Mycobacterium tuberculosis detection in clinical samples. J Clin Microbiol. 2011;49:3458-62.

59. Moure R, Martín R, Alcaide F. Effectiveness of an integrated real-time PCR method for detection of the Mycobacterium tuberculosis complex in smear-negative extrapulmonary samples in an area of low tuberculosis prevalence. J Clin Microbiol. 2012;50:513-5.

60. Park KS, Kim JY, Lee JW, Hwang YY, Jeon K, Koh WJ, et al. Comparison of the Xpert MTB/RIF and Cobas TaqMan MTB assays for detection of Mycobacterium tuberculosis in respiratory specimens. J Clin Microbiol. 2013:51:3225-7.

61. Pinhata JMW, Cergole-Novella MC, dos Santos Carmo AM, Ferro e Silva RR, Ferrazoli L, Sacchi CT, et al. Rapid detection of Mycobacterium tuberculosis complex by real-time PCR in sputum samples and its use in the routine diagnosis in a reference laboratory. J Med Microbiol. 2015;64:1040-5.

62. Rosso F, Michelon CT, Sperhacke RD, Verza M, Olival L, Conde MB, et al. Evaluation of real-time PCR of patient pleural effusion for diagnosis of tuberculosis. BMC Res Notes. 2011:4:279-84.

63. Seith S, Yadav R, Mewara A, Dhatwalia SK, Sharma M, Gupta D. Evaluation of in-house mpt64 real-time PCR for rapid detection of Mycobacterium tuberculosis in pulmonary and extrapulmonary specimens. Braz J Infect Dis. 2012;16:493-4.

64. Sharma SK, Kohli M, Yadav RN, Chaubey J, Bhasin D, Sreenivas V, et al. Evaluating the diagnostic accuracy of Xpert MTB/RIF assay in pulmonary tuberculosis. PLoS One. 2015;10(10):e0141011. https://doi.org/10.1371/ journal.pone.0141011.

65. Tortoli E, Urbano P, Marcelli F, Simonetta MT, Cirillo MD. Is real-time PCR better than conventional PCR for Mycobacterium tuberculosis complex detection in clinical samples? J Clin Microbiol. 2012;50:2810-3.

66. Wang X, YH W, Zhang K, Guan C, Gao X, Wang M. Value of real-time polymerase chain reaction in bronchoalveolar lavage fluid for diagnosis of pediatric pulmonary tuberculosis. Braz J Infect Dis. 2013;17:718-9.

67. Yang YC, PL L, Huang SC, Jenh YS, Jou R, Chang TC. Evaluation of the Cobas TaqMan MTB test for direct detection of Mycobacterium tuberculosis complex in respiratory specimens. J Clin Microbiol. 2011:49:797-801.

68. Lange C, Mori T. Advances in the diagnosis of tuberculosis. Respirology. 2010;15:220-40.

69. Liu KT, WJ S, Perng RP. Clinical utility of polymerase chain reaction for diagnosis of smear-negative pleural tuberculosis. J Chin Med Assoc. 2007;70:148-51

70. Haldar S, Bose M, Chakrabarti P, Daginawala HF, Harinath BC, Kashyap RS, et al. Improved laboratory diagnosis of tuberculosis-the Indian experience. Tuberculosis. 2011:91:414-26.

71. Derese Y, Hailu E, Assefa T, Bekele Y, Mihret A, Aseffa A, et al. Comparison of PCR with standard culture of fine needle aspiration samples in the diagnosis of tuberculosis lymphadenitis. J Infect Dev Ctries. 2012;6:53-7. 
72. Padmavathy $L$, Rao $L$, Veliath $A$. Utility of polymerase chain reaction as a diagnostic tool in cutaneous tuberculosis. Indian J Dermatol Venereol Leprol. 2003;69:214-6.

73. Sharma SK, Mohan A. Extrapulmonary tuberculosis. Indian J Med Res. 2004;120:316-53.

74. Takahashi T, Tamura M, Asami Y, Kitamura E, Saito K, Suzuki T, et al. Novel wide-range quantitative nested real-time PCR assay for Mycobacterium tuberculosis DNA: clinical application for diagnosis of tuberculous meningitis. J Clin Microbiol. 2008;46:1698-707.

75. Mehta PK, Kalra M, Khuller GK, Behera D, Verma I. Development of an ultrasensitive polymerase chain reaction amplified immunoassay (Immuno-PCR) based on mycobacterial RD antigens: implications for the serodiagnosis of tuberculosis. Diagn Microbiol Infect Dis. 2012;72:166-74.

76. Almadi MA, Ghosh S, Aljebreen AM. Differentiating intestinal tuberculosis from Crohn's disease: a diagnostic challenge. Am J Gastroenterol. 2009;104:1003-12.

77. Bravo FG, Gotuzzo E. Cutaneous tuberculosis. Clin Dermatol. 2007;25:173-80.

78. Chawla K, Gupta S, Mukhopadhyay C, Rao PS, Bhat SS. PCR for M. Tuberculosis in tissue samples. J Infect Dev Ctries. 2009;3:83-7.

79. Petitti DB. Approaches to heterogeneity in meta-analysis. Stat Med. 2001;20:3625-33.

80. Abbara A, Davidson RN. Etiology and management of genitourinary tuberculosis. Nat Rev Urol. 2011;8:678-88.

81. Baba K, Pathak S, Sviland L, Langeland N, Hoosen AA, Asjo B, et al. Real-time quantitative PCR in the diagnosis of tuberculosis in formalin-fixed paraffin-embedded pleural tissue in patients from a high HIV endemic area. Diagn Mol Pathol. 2008;17:112-7.

82. Kalantri Y, Hemvani N, Chitnis DS. Evaluation of real-time polymerase chain reaction, interferon-gamma, adenosine deaminase, and immunoglobulin A for the efficient diagnosis of pleural tuberculosis. Intern. J Infect Dis. 2011;15:e226-31.

83. Katoch VM. Newer diagnostic techniques for tuberculosis. Indian J Med Res. 2004;120:418-28.

84. Song F, Eastwood A, Gilbody S, Duley D, Sutton AJ. Publication and related biases. Health Technol Assess. 2000;4:53-5.

85. Reid MC, Lachs MS, Feinstein AR. Use of methodological standards in diagnostic test research. Getting better but still not good. JAMA. 1995;274:645-51.

86. Small PM, Perkins MD. More rigour needed in trials of new diagnostic agents for tuberculosis. Lancet. 2000;356:1048-9.

87. National Collaborating Centre for Chronic Conditions. Tuberculosis: clinical diagnosis and management of tuberculosis and measures for its prevention and control. London: Royal College of Physicians; 2006.

88. Kulkarni S, Rajan MGR, Hazra P, Islam A. Development of a TB-PCR kit for the diagnosis of tuberculosis. BARC Newsletter. 2011;319:44-50.

89. Galimi R. Extrapulmonary tuberculosis: tuberculous meningitis new developments. Eur Rev Med Pharmacol Sci. 2011;15:365-86.

90. Pandey V, Chawla K, Acharya K, Rao S, Rao S. The role of polymerase chain reaction in the management of osteoarticular tuberculosis. Int Orthop. 2009;33:801-5.

91. Reporting of Diagnostic Accuracy steering group. Towards complete and accurate reporting of studies of diagnostic accuracy: the STARD initiative. BMJ. 2003;326:41-4.

\section{Submit your next manuscript to BioMed Central and we will help you at every step:}

- We accept pre-submission inquiries

- Our selector tool helps you to find the most relevant journal

- We provide round the clock customer support

- Convenient online submission

- Thorough peer review

- Inclusion in PubMed and all major indexing services

- Maximum visibility for your research

Submit your manuscript at www.biomedcentral.com/submit 